\title{
Dyeability of Polyester and Polyamide Fabrics Employing Citric Acid
}

\author{
Renee Simoes Argolo do Carmo ${ }^{1 *}$, Luciana Juncioni de Arauz ${ }^{2}$, Jorge Marcos Rosa ${ }^{1,3}$, \\ Julia Baruque-Ramos ${ }^{1}$, Mauricio de Campos Araujo ${ }^{1}$
}

${ }^{1}$ School of Arts, Sciences and Humanities, University of Sao Paulo, Sao Paulo, Brazil

${ }^{2}$ Adolfo Lutz Institute, Sao Paulo, Brazil

${ }^{3}$ College of Technology SENAI “Antoine Skaf”, Sao Paulo, Brazil

Email: ${ }^{*}$ carmo200@uol.com.br

How to cite this paper: Carmo, R.S.A., Arauz, L.J., Rosa, J.M. Baruque-Ramos, J. and Araujo, M.C. (2017) Dyeability of Polyester and Polyamide Fabrics Employing Citric Acid. Journal of Textile Science and Technology, 3, 31-44.

https://doi.org/10.4236/jtst.2017.33003

Received: July 27, 2017

Accepted: August 27, 2017

Published: August 30, 2017

Copyright ( 2017 by authors and Scientific Research Publishing Inc. This work is licensed under the Creative Commons Attribution International License (CC BY 4.0).

http://creativecommons.org/licenses/by/4.0/

\section{(c) (i) Open Access}

\begin{abstract}
The employment of sustainable chemicals, such as citric acid, represents a possibility for the development of textile dyeing processes. This study aimed to analyze the possibility of replacement of acetic acid (commonly used in textile processing) by citric acid in polyester and polyamide 6 dyeing processes. The utilization of citric acid as leveling agent for disperse dyestuffs was also investigated. Dyeing processes in turquoise color for these fabrics were performed employing citric and acetic acid. Color differences between dyeing processes and color fastness to water were evaluated. All the color dyeing differences were not significant and there was no transference in color fastness tests (grade 5). Otherwise, the differences among polyamide dyeing processes could be related to the efficiency of citric acid solution as sequestering agent. Notwithstanding citric acid to be more expensive than acetic acid and the need of previous dissolution by stirring, it could be advantageous for some formulations.
\end{abstract}

\section{Keywords}

Citric Acid, Acetic Acid, Textile Industry, Polyester, Polyamide, Dyeing

\section{Introduction}

Textile industry involves processing or converting raw material into finished textile materials via several processes which consume large amount of water and generate polluting waste effluents containing nonbiodegradable and dissolved toxic substances [1]. Among the various processes, fabric dyeing releases large amounts of toxic chemical products, for both human health and environment, which results in a mixed wastewater composed of residual dyes, auxiliary chem- 
icals, surfactants, chlorinated compounds and salts [2] [3].

Dyeing is the process of adding color to textile products like fibers, yarns, and fabrics. It is normally done in a solution containing dyes and chemicals. The dyeing process of fibers and/or textiles comprises four processes: diffusion of dye in the solution, adsorption at the fiber surface, diffusion into the fiber and fixation of the dye to the fiber. The diffusion of dye into fiber depends on $\mathrm{pH}$, temperature and employs auxiliary agents as well [4].

Although the majority of commercial textile dyes are water soluble, some dyes present hydrophobic behavior, especially the disperse dyes that are used for dyeing polyester fabrics [5]. Disperse dyes are non-ionic aromatic compounds bearing azo or anthraquinone as a chromophore group. The dyes are applied to the fibers by stable aqueous dispersion containing auxiliaries, especially dispersants at high temperature. Under this condition, the disperse dyes are dissolved, adsorbed onto the fiber surface and then transferred into the synthetic fiber. However, after the dyeing process finishes, the non-adsorbed dyes combine with the dispersing agents, which are components of the residual dyeing liquor and are sent to the treatment system. This process leads to an increased presence of dyes in wastewaters from textile processing plants [6].

Environmental issues are being increasingly taken into account in textile dyeing and finishing processes because of strict legislations and a growing ecological concern [7]. For this purpose, the application of biological treatment based in technologies for treating textile wastewater has attracted interest. In this context, it is proposed the use of microorganisms [8], plants [9], photoreactor combining UV light and $\mathrm{TiO}_{2}$ among others [10]. In addition, efforts to reduce water consumption are relevant [11].

On the other hand, during the production process controlling pollution is as vital as making a product less harmful and with ecological benefits to the environmental. A number of sustainable and ecofriendly practices have been implemented by various textile processing industries, such as: ecofriendly bleaching; peroxide bleaching; ecofriendly dyeing and printing; low impact dyes; natural dyes; azo free dyes; phthalates free printing [12].

Additionally, input material change involves substituting one material for another, which is less harmful to the environment, more feasible to use and has the same or better technical requirements [12]. In this context, Pasquet et al. [7] stated that vanillin can be used as potential carrier, nontoxic, for the chemical substitution of toxic carriers for polyester fabric dyeing process. Bischof et al. [13] reported the action of citric acid on cotton textiles as efficient antibacterial agent for prevention of nosocomial infections. Jaeger et al. [14] demonstrated the results of tolerability of a new citric acid coated fabric and its impact on skin physiology in patients with atopic eczema or atopic diathesis. These studies indicate that, in the near future, it will be possible to make these environmentally friendly products and processes viable to modern textile industry [15].

Acetic acid, toxic in high concentration, is generally used for adjusting the dyebath $\mathrm{pH}$ value in dyeing process [16], although a buffer system containing 
formic acid and ammonium sulfate can be used as well [17].

Citric acid is a weak organic acid that is found in many fruits and vegetables especially citrus. The compound is produced by fermentation and used primarily in the foods, beverages, pharmaceutical, chemical, textile and electroplating industries. This acid is widely used in food industry, but it also finds applications as a function of additive detergents, pharmaceuticals, cosmetics and toiletries [18]. It contributes to the formulation of many foods as an acidulant, antioxidant, emulsifier or preservative and there is great world-wide demand for citric acid due to its low toxicity when compared with other acidulants. Thereby, citric acid is safer to the environment and public health [19]. It is biodegradable, ecofriendly, economical, safe and a versatile chemical for sequestering, buffering, wetting, cleaning and dispersing [20].

Thus, articulating the requirements for industrial application of sustainable chemistry, the use of citric acid in textile dyeing technologies can be a viable alternative. It is important to mention that in textile industry many employed empirical methods and practices have not been yet subjected to strict scientific studies and published in literature. In this way, despite of the employment of citric acid in textile processes is not novel; the present authors did not found reports in literature on the use of citric acid in polyamide dyeing. In this context, the present study reports the possibility of substituting acetic by citric acid in textile dyeing process. Considerations about employment possibilities and environmental impacts were accomplished according literature data.

\section{Materials and Methods}

\subsection{Fabric Samples}

The fabric samples were obtained from local market in Sao Paulo State: i) jersey knitted fabric-100\% polyester previously scoured (Conformatec Textile Industry, Brazil) and ii) jersey knitted fabric-100\% polyamide 6 previously scoured (Brazilian Service for Industrial Apprenticeship-SENAI, Brazil).

\subsection{Textile Dyestuffs and Chemicals}

Lactic acid (98.0\%), malic acid (99.0\%), tartaric acid (99.0\%), glacial acetic acid (99.5\%), sodium hydroxide and calcium chloride were obtained from Quimesp Quimica Ltda (Brazil). Turquoise disperse dye Quimacron C-2GN-200 and turquoise acid dye Quimanylon N-5G were purchased from Quimanil Produtos Quimicos Ltda (Brazil). Sequestering agent Ladiquest 1097 and polyamide fixer agent Nylofixan PAN were acquired from Clariant (Brazil). Disperse dyestuff levelling agent Setamol WS (based on sulfonated naphthalene) and anhydrous citric acid 99.5\% were purchased from BASF S/A (Brazil) and Casa Americana de Artigos para Laboratorios (CAAL, Brazil), respectively. Distilled water was used as solvent for preparation of reagents.

\subsection{Complex Ions Formation}

A $1 \mathrm{~g}$ sample of tested sequestering agent was dissolved in $80 \mathrm{~mL}$ of distilled wa- 
ter and $10 \mathrm{~mL}$ of calcium carbonate solution $2 \%$. The $\mathrm{pH}$ was adjusted to 11 with a sodium hydroxide solution $2 \%$. The resulting solution was titrated with a solution of dihydrate calcium chloride $48.7 \mathrm{~g} / \mathrm{L}$. The determination of sequestering power was determined according to the Hampshire test [21] by the Equation (1):

$$
1 \mathrm{mg} \mathrm{CaCO}{ }_{3}=\frac{33.15 \times\left(\text { spent volume of } \mathrm{CaCl}_{2}\right)}{\text { sample weight }}
$$

\subsection{Citric acid as Disperse Dye Levelling Agent}

In this qualitative test, the dyeing process was carried out without textile substrate. The dyeing solution was prepared with turquoise disperse dye (Quimacron C-2GN-200, $3 \mathrm{~g} / \mathrm{L}$ ) and disperse dyestuff levelling (Setamol WS, $2 \mathrm{~g} / \mathrm{L}$ ). The $\mathrm{pH}$ of the dyebath was adjusted to 4.0 employing aqueous solutions of acetic or citric acid. The dyebath was heated until $130^{\circ} \mathrm{C}$ and kept at this temperature for $30 \mathrm{~min}$. Afterwards, the bath was cooled to $80^{\circ} \mathrm{C}$ and the solution was vacuum filtered through a filter membrane of $0.45 \mu \mathrm{m}$ pore size. The parameters are shown at Table 1 .

\subsection{Dyeing Processes}

Dyeing experiments were carried out with polyester and polyamide fabrics in two types of dyebath: i) water with a hardness of $\mathrm{CaCO}_{3} 200 \mathrm{ppm}$ and ii) potable water for public consumption (containing chlorine near $0.2 \mathrm{mg} / \mathrm{L}$ and fluorine $0.7 \mathrm{mg} / \mathrm{L}$ ) [22]. The polyester fabric dyeing was performed in laboratory scale HT equipment (Mathis, ALT-1). Polyester dyeing was performed by raising the dyebath temperature to $130^{\circ} \mathrm{C}$ at a rate of $2^{\circ} \mathrm{C} / \mathrm{min}$, holding at this temperature for 40 min followed by cooling. Polyamide 6 dyeing was carried out by raising the dyebath temperature to $96^{\circ} \mathrm{C}$ at a rate of $2^{\circ} \mathrm{C} / \mathrm{min}$, holding at this temperature for 40 min followed by cooling [23]. After polyamide 6 dyeing, fixer agent (Nylofixan PAN, 4\%) was applied. The parameters for both dyeing process are shown at Table 2.

\subsection{Evaluation of Color Differences between Dyeing Processes and Color Fastness to Water}

The colorimetric parameters of the dyed fabrics were determined by reflectance spectrophotometer VIS (Konika Minolta CM $3600 \mathrm{~d}$ ) in order to check the possible color differences between the obtained results from dyeing experiments employing the CIELab system [24].

Table 1. Concentrations of reagents for experiments of replacement of polyester dispersing agents by acetic or citric acid solution.

\begin{tabular}{rcccc}
\hline Experiments & 1 & 2 & 3 & 4 \\
\hline Acetic Acid & pH 4.0 & pH 4.0 & ---- & --- \\
Citric Acid & ---- & ---- & $\mathrm{pH} 4.0$ & $0.5 \mathrm{~g} / \mathrm{L}$ \\
Setamol WS & ---- & $2.0 \mathrm{~g} / \mathrm{L}$ & $2.0 \mathrm{~g} / \mathrm{L}$ & ---- \\
\hline
\end{tabular}


Table 2. Concentrations of reagents for dyeing process experiments of polyester ${ }^{\mathrm{a}}$ and polyamide $6^{\mathrm{b}}$ fabrics.

\begin{tabular}{|c|c|c|c|c|c|c|}
\hline \multirow{2}{*}{$\begin{array}{l}\text { Type of water } \\
\text { Experiments }\end{array}$} & \multicolumn{3}{|c|}{ Public supply water } & \multicolumn{3}{|c|}{ Water with $\mathrm{CaCO}_{3} 200$ ppm } \\
\hline & Control & (1) & (2) & (3) & $(4)$ & (5) \\
\hline Citric Acid & ----- & $0.5 \mathrm{~g} / \mathrm{L}$ & ---- & ----- & $0.5 \mathrm{~g} / \mathrm{L}$ & ---- \\
\hline Acetic Acid & $0.5 \mathrm{~g} / \mathrm{L}$ & ----- & $0.5 \mathrm{~g} / \mathrm{L}$ & $0.5 \mathrm{~g} / \mathrm{L}$ & ----- & $0.5 \mathrm{~g} / \mathrm{L}$ \\
\hline Sequestering agent ${ }^{c}$ & ---- & ---- & $0.5 \mathrm{~g} / \mathrm{L}$ & ---- & ---- & $0.5 \mathrm{~g} / \mathrm{L}$ \\
\hline
\end{tabular}

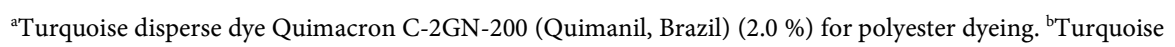
acid dye Quimanylon N-5G (Quimanil, Brazil) (2.0\%) for polyamide 6 dyeing. 'Ladiquest 1097 (Clariant, Brazil).

For the determination of differences between dyeing results, it is calculated the $\Delta \mathrm{E}^{\star}$ value applying Equation (2):

$$
\Delta E^{*}=\left[\left(\Delta a^{*}\right)^{2}+\left(\Delta b^{*}\right)^{2}+\left(\Delta L^{*}\right)^{2}\right]^{1 / 2}
$$

The equation allows to calculating de Euclidian distance between two colors in the CIELab space, described as:

- $a^{*}$-red/green axis-meaning if the value is positive the sample is redder, or negative, greener;

- $b^{*}$-blue/yellow axis-meaning if the value is positive the sample is yellower, or negative, bluer and;

- $L^{*}$-white/black axis-meaning if the value is positive the sample is clearer, or negative, darker.

Color fastness tests to water were carried out on turquoise dyed polyester and polyamide 6 fabric samples according the test method ABNT NBR ISO 105-E01: 2014-Textiles-Tests for color fastness Part E01: color fastness to water [25]. The results were assessed by spectrophotometry VIS (Konica-Minolta CM 3600 d) under illuminant D65, $10^{\circ}$. The software grey scale has grades 1 to 5 and increases by half of grade $(1,11 / 2,2,21 / 2$ and so on.) with value 5 being the highest and best evaluation.

\section{Results and Discussion}

\subsection{Complex Ions Formation}

The values for acetic, citric, lactic, malic and tartaric acid tested on the sequestering power evaluation of the Hampshire test were: zero; 366.71; 19.84; 54.06; and $17.28 \mathrm{mg} \mathrm{CaCO}_{3} /(\mathrm{g}$ of product) respectively. The results showed that acetic acid has no presented sequestering action whereas citric acid has a similar complexing action of the calcium ions as compared to the commercial sequestering agent tested (Ladiquest 1097) correspondent to $231.1 \mathrm{mg} \mathrm{CaCO}_{3} /(\mathrm{g}$ of product).

\subsection{Citric Acid as Disperse Dye Levelling Agent}

The experiments were carried out in order to simulate the normal conditions of polyester fabric dyeing solution preparation with the use of auxiliary chemicals in a process with a range of $\mathrm{pH} 4.5$ - 5.5. However, instead of being employed for 
dyeing textile substrate, they were filtered. The dyebaths were vacuum filtrated in filter membrane of $0.45 \mu \mathrm{m}$ pore size. The orifice marks formed in membranes upon filtration were circular with dark turquoise color. Dispersion test results represented by these orifice marks in membranes are presented in Figure 1. The best results were considered for funnel membrane orifices with higher definition (Figure 1(c) and Figure 1(d)), in which citric acid was present in composition. The other membranes (Figure 1(a) and Figure 1(b)) with acetic acid in composition exhibited slighter color orifice marks. Membrane control with no product was also carried out. These data showed that citric acid solution, compared to acetic acid solution, presents superior effectiveness. Additionally, citric acid solution showed a greater dispersant action than Setamol WS dispersant (BASF, Brazil), which is commonly employed in industrial textile processes. It is noteworthy that no scientific literature was found relative to quantitative analytical methods in order to demonstrate the effectiveness of dispersion of disperse dyes.

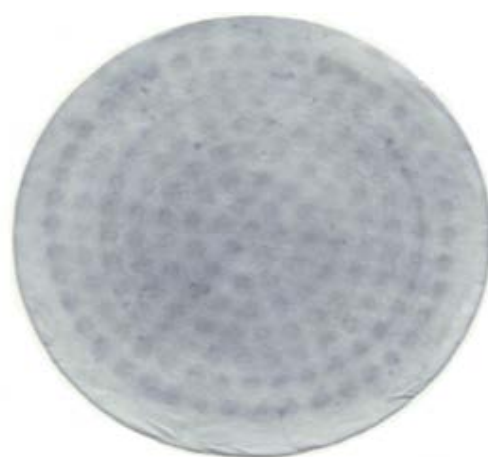

(a)

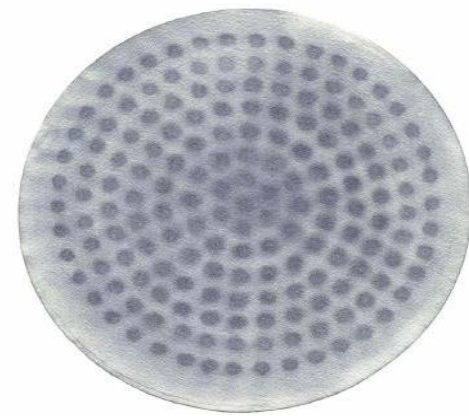

(c)

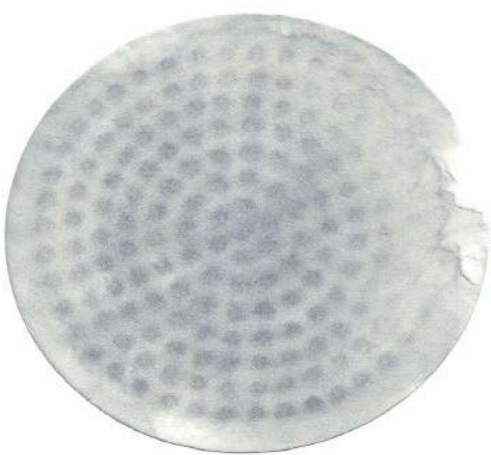

(b)

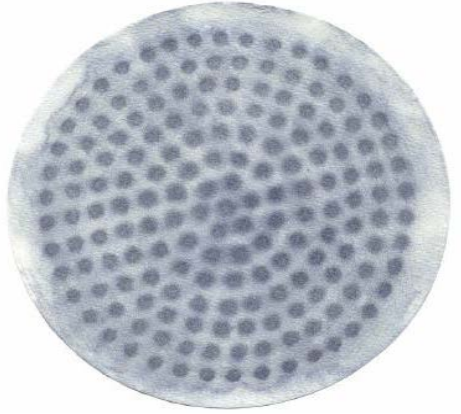

(d)

Figure 1. Test results of disperse dye dispersing agents: (a)acetic acid $\mathrm{pH} 4.0$; (b)acetic acid with Setamol WS $2.0 \mathrm{~g} / \mathrm{L}$ ( $\mathrm{pH} 4.0$ ); (c)citric acid with Setamol WS $2.0 \mathrm{~g} / \mathrm{L}$ (pH 4.0); (d) citric acid $0.5 \mathrm{~g} / \mathrm{L}$. The best dispersion results are shown in (c) and (d), both ones containing citric acid in the preparation.

\subsection{Color Difference Evaluation in Dyeing Processes}

Color differences in dyed samples could not be observed accurately by visual comparison. In this way, separately for polyester and polyamide 6 analysis, spectrophotometry was utilized to measure the color parameters in three dyed fabric 
samples (two verifications in each one), resulting in six color results. A reference sample containing only the dye and acetic acid solution $(0.5 \mathrm{~g} / \mathrm{L})$ in dyeing process was used as control. For the determination of differences between dyeing results, $\Delta \mathrm{E}$ values were calculated. Averages and standard deviations are presented in Table 3 . The $\Delta \mathrm{E}$ values up to 1.0 are commercially acceptable. According this criterion, all the colors variations achieved for polyamide 6 and polyester samples were acceptable, that is, these differences were commercially not significant (Table 3).

In Table 4 the obtained probabilities from a Student's test $t$ (at $5 \%$ significance level) from comparisons of results from different dyeing processes were shown. The probabilities for polyester dyeing processes are mainly superior to $5 \%$. Therefore, there was no statistically significant difference among the averages for polyester dyeing processes. In this case, it is important mention that polyester dyeing processes presented lower $\Delta \mathrm{E}$ averages and standard deviations than polyamide dyeing processes (Table 3 ).

However, for polyamide 6 dyeing processes all probabilities for no difference among the averages were inferior to $5 \%$, exception the comparisons between (2) public supply water with acetic acid $0.5 \mathrm{~g} / \mathrm{L}$ and sequestering agent $0.5 \mathrm{~g} / \mathrm{L}$ and (3) hard water (with $\mathrm{CaCO}_{3} 200 \mathrm{mg} / \mathrm{L}$ ) with acetic acid $0.5 \mathrm{~g} / \mathrm{L}$ (probability of 24.4\%); and between (3) hard water (with $\mathrm{CaCO}_{3} 200 \mathrm{mg} / \mathrm{L}$ ) with acetic acid 0.5 $\mathrm{g} / \mathrm{L}$ and (5) hard water (with $\mathrm{CaCO}_{3} 200 \mathrm{mg} / \mathrm{L}$ ) with acetic acid $0.5 \mathrm{~g} / \mathrm{L}$ and sequestering agent $0.5 \mathrm{~g} / \mathrm{L}$ (probability of $8.4 \%$ ) (Table 4). It is noteworthy that dyeing polyamide 6 processes in citric acid solution presented the lowest $\Delta \mathrm{E}$ averages compared with the other ones in this substrate (Table 4). These differences among polyamide dyeing processes could be related to the efficiency of citric acid solution as a sequestering agent for calcium salt in dyebaths, improving the dyeing polyamide 6 processes.

Additionally, the visual observation of all samples (polyester and polyamide 6) has not found failures in the dyeing processes, as stains or fades, which could cause irreparable damage to the appearance of fabrics (data not shown).

Table 3. Results of $\Delta \mathrm{E}$ for polyester or polyamide 6 (calculated from the points correspondent to results of dyeing processes performed with public supply water and acetic acid $0.5 \mathrm{~g} / \mathrm{L}$ ). The results are expressed as average and standard deviation.

\begin{tabular}{|c|c|c|}
\hline Dyeing & Polyamide 6 & Polyester \\
\hline (1) Public supply water with citric acid $0.5 \mathrm{~g} / \mathrm{L}$ & $0.50 \pm 0.21$ & $0.39 \pm 0.11$ \\
\hline $\begin{array}{l}\text { (2) Public supply water with acetic acid } 0.5 \mathrm{~g} / \mathrm{L} \\
\text { and sequestering agent }{ }^{\mathrm{a}} 0.5 \mathrm{~g} / \mathrm{L}\end{array}$ & $0.84 \pm 0.16$ & $0.29 \pm 0.08$ \\
\hline $\begin{array}{l}\text { (3) Hard water (with } \mathrm{CaCO}_{3} 200 \mathrm{mg} / \mathrm{L} \text { ) } \\
\text { with acetic acid } 0.5 \mathrm{~g} / \mathrm{L}\end{array}$ & $0.94 \pm 0.11$ & $0.24 \pm 0.06$ \\
\hline $\begin{array}{l}\text { (4) Hard water (with } \mathrm{CaCO}_{3} 200 \mathrm{mg} / \mathrm{L} \text { ) } \\
\text { with citric acid } 0.5 \mathrm{~g} / \mathrm{L}\end{array}$ & $0.77 \pm 0.10$ & $0.26 \pm 0.02$ \\
\hline $\begin{array}{l}\text { (5) Hard water (with } \mathrm{CaCO}_{3} 200 \mathrm{mg} / \mathrm{L} \text { ) with } \\
\text { acetic acid } 0.5 \mathrm{~g} / \mathrm{L} \text { and sequestering agent }{ }^{\mathrm{a}} 0.5 \mathrm{~g} / \mathrm{L}\end{array}$ & $1.07 \pm 0.13$ & $0.31 \pm 0.05$ \\
\hline
\end{tabular}

${ }^{\mathrm{a}}$ Ladiquest 1097 (Clariant, Brazil). 
Table 4. Test $\mathrm{t}$ probability relative to comparison of $\Delta \mathrm{E}$ of different dyeing processes ( $5 \%$ significance level).

\begin{tabular}{|c|c|c|}
\hline \multirow[t]{2}{*}{ Comparison of results from different dyeing processes } & \multicolumn{2}{|c|}{ Test t probability (\%) } \\
\hline & Polyamide 6 & Polyester \\
\hline $\begin{array}{l}\text { (1) Public supply water with citric acid } 0.5 \mathrm{~g} / \mathrm{L} \\
\mathrm{X} \\
\text { (2) Public supply water with acetic acid } 0.5 \mathrm{~g} / \mathrm{L} \\
\text { and sequestering agent }{ }^{\mathrm{a}} 0.5 \mathrm{~g} / \mathrm{L}\end{array}$ & 1.0 & 7.9 \\
\hline $\begin{array}{l}\text { (1) Public supply water with citric acid } 0.5 \mathrm{~g} / \mathrm{L} \\
\mathrm{X} \\
\text { (3) Hard water (with } \mathrm{CaCO}_{3} 200 \mathrm{mg} / \mathrm{L} \text { ) with acetic acid } 0.5 \mathrm{~g} / \mathrm{L}\end{array}$ & 0.1 & 1.4 \\
\hline $\begin{array}{l}\text { (1) Public supply water with citric acid } 0.5 \mathrm{~g} / \mathrm{L} \\
\mathrm{X} \\
\text { (4) Hard water (with } \mathrm{CaCO}_{3} 200 \mathrm{mg} / \mathrm{L} \text { ) with citric acid } 0.5 \mathrm{~g} / \mathrm{L}\end{array}$ & 1.7 & 1.4 \\
\hline $\begin{array}{l}\text { (1) Public supply water with citric acid } 0.5 \mathrm{~g} / \mathrm{L} \\
\mathrm{X} \\
\text { (5) Hard water (with } \mathrm{CaCO}_{3} 200 \mathrm{mg} / \mathrm{L} \text { ) with } \\
\text { acetic acid } 0.5 \mathrm{~g} / \mathrm{L} \text { and sequestering agent }{ }^{\mathrm{a}} 0.5 \mathrm{~g} / \mathrm{L}\end{array}$ & 0.02 & 11.9 \\
\hline $\begin{array}{l}\text { (2) Public supply water with acetic acid } 0.5 \mathrm{~g} / \mathrm{L} \\
\text { and sequestering agent }{ }^{\mathrm{a}} 0.5 \mathrm{~g} / \mathrm{L} \\
\mathrm{X} \\
\text { (3) Hard water (with } \mathrm{CaCO}_{3} 200 \mathrm{mg} / \mathrm{L} \text { ) with acetic acid } 0.5 \mathrm{~g} / \mathrm{L}\end{array}$ & 24.4 & 29.0 \\
\hline $\begin{array}{l}\text { (2) Public supply water with acetic acid } 0.5 \mathrm{~g} / \mathrm{L} \\
\text { and sequestering agent }{ }^{\mathrm{a}} 0.5 \mathrm{~g} / \mathrm{L} \\
\mathrm{X} \\
\text { (4) Hard water (with } \mathrm{CaCO}_{3} 200 \mathrm{mg} / \mathrm{L} \text { ) with citric acid } 0.5 \mathrm{~g} / \mathrm{L}\end{array}$ & 3.8 & 38.9 \\
\hline $\begin{array}{l}\text { (2) Public supply water with acetic acid } 0.5 \mathrm{~g} / \mathrm{L} \\
\text { and sequestering agent } \mathrm{t}^{\mathrm{a}} 0.5 \mathrm{~g} / \mathrm{L} \\
\mathrm{X} \\
\text { (5) Hard water (with } \mathrm{CaCO}_{3} 200 \mathrm{mg} / \mathrm{L} \text { ) with } \\
\text { acetic acid } 0.5 \mathrm{~g} / \mathrm{L} \text { and sequestering agent } \mathrm{a}^{\mathrm{a}} 0.5 \mathrm{~g} / \mathrm{L}\end{array}$ & 2.0 & 53.3 \\
\hline $\begin{array}{l}\text { (3) Hard water (with } \mathrm{CaCO}_{3} 200 \mathrm{mg} / \mathrm{L} \text { ) with acetic acid } 0.5 \mathrm{~g} / \mathrm{L} \\
\mathrm{X} \\
\text { (4) Hard water (with } \mathrm{CaCO}_{3} 200 \mathrm{mg} / \mathrm{L} \text { ) with citric acid } 0.5 \mathrm{~g} / \mathrm{L}\end{array}$ & 1.9 & 55.0 \\
\hline $\begin{array}{l}\text { (3) Hard water (with } \mathrm{CaCO}_{3} 200 \mathrm{mg} / \mathrm{L} \text { ) with acetic acid } 0.5 \mathrm{~g} / \mathrm{L} \\
\mathrm{X} \\
\text { (5) Hard water (with } \mathrm{CaCO}_{3} 200 \mathrm{mg} / \mathrm{L} \text { ) with } \\
\text { acetic acid } 0.5 \mathrm{~g} / \mathrm{L} \text { and sequestering agent }{ }^{\mathrm{a}} 0.5 \mathrm{~g} / \mathrm{L}\end{array}$ & 8.4 & 5.1 \\
\hline $\begin{array}{l}\text { (4) Hard water (with } \mathrm{CaCO}_{3} 200 \mathrm{mg} / \mathrm{L} \text { ) with citric acid } 0.5 \mathrm{~g} / \mathrm{L} \\
\mathrm{X} \\
\text { (5) Hard water (with } \mathrm{CaCO}_{3} 200 \mathrm{mg} / \mathrm{L} \text { ) with } \\
\text { acetic acid } 0.5 \mathrm{~g} / \mathrm{L} \text { and sequestering agent }{ }^{\mathrm{a}} 0.5 \mathrm{~g} / \mathrm{L}\end{array}$ & 0.1 & 2.6 \\
\hline
\end{tabular}

${ }^{a}$ Ladiquest 1097 (Clariant, Brazil).

\subsection{Color Fastness to Water Tests}

As presented in Figure 2 and Figure 3, no significant changes were observed in dyed polyester or polyamide 6 fabrics employing acetic and citric acid solutions in public supply or hard water. In addition, grade 5 was achieved on the color transference tests. Consequently, the utilization of citric acid solution will not affect the color quality of the dyed fabrics compared to the process employing acetic acid solution. The results shown in Figure 3 for polyester dyed fabrics are 


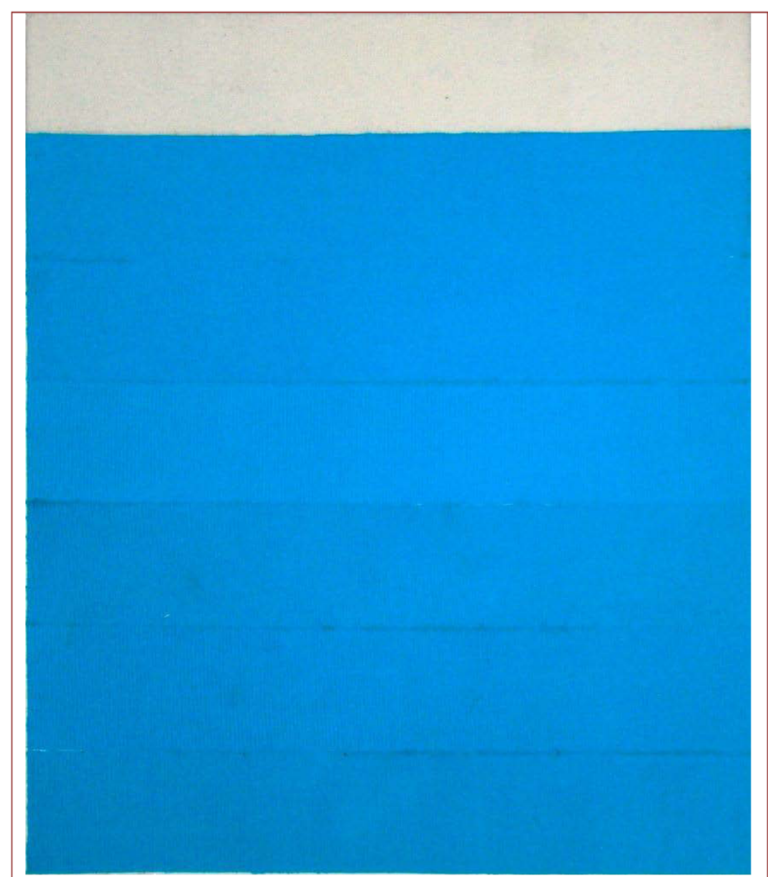

(a)

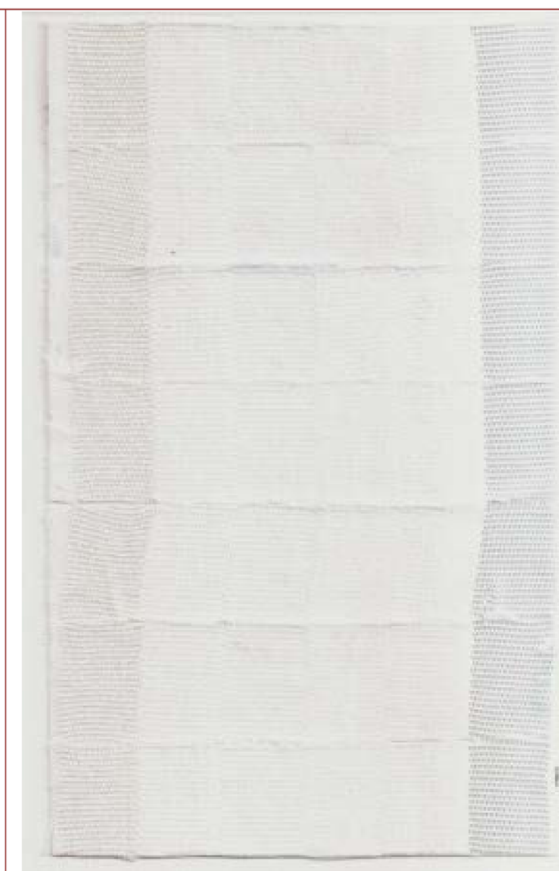

(b)

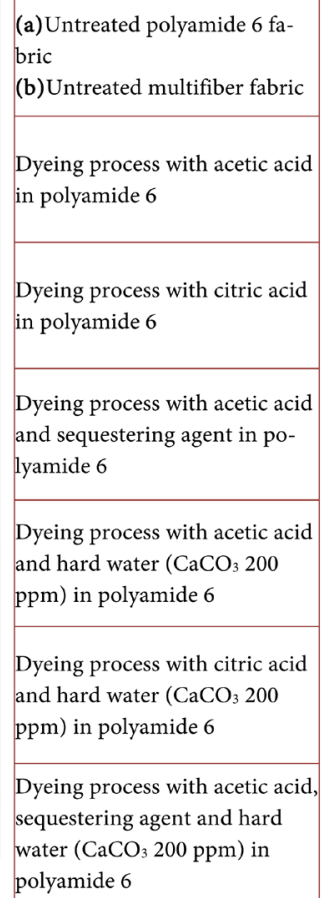

Figure 2. (a) Comparative dyeing results on polyamide 6 fabric; (b) Respective results for polyamide 6 dyeing for color fastness to water tests.

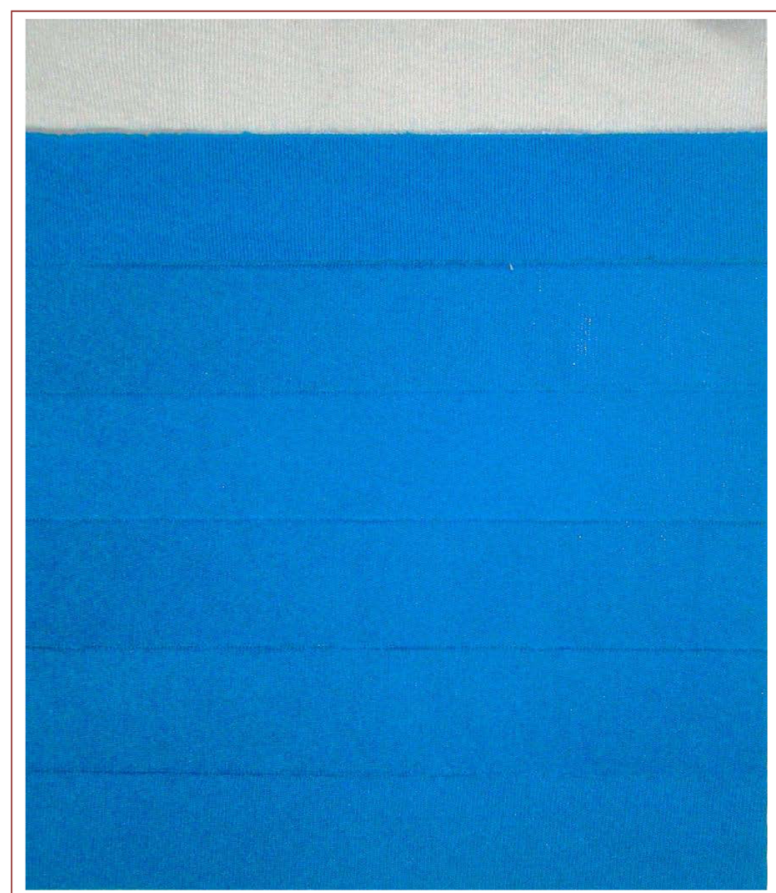

(a)

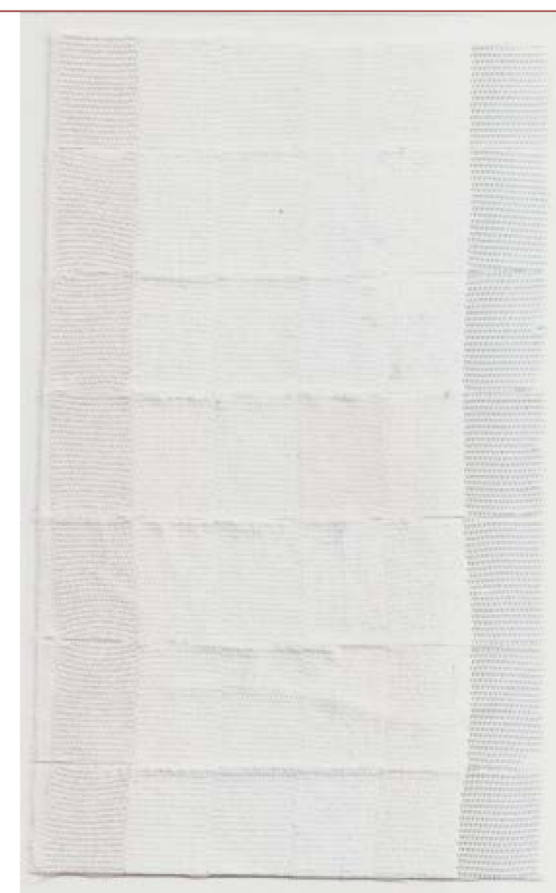

(b)

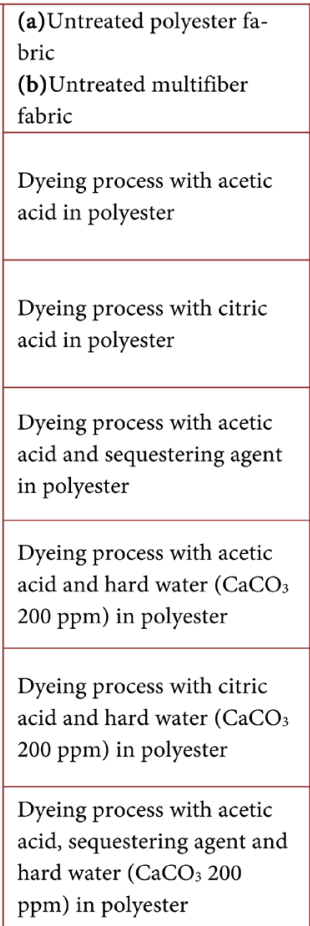

Figure 3. (a) Comparative dyeing results on polyester fabric; (b) Respective results for polyester dyeing for color fastness to water tests. in accordance with Miljkovic et al. [17] that found no significant differences in dyeing processes of polyester fabric with the use of acetic and citric acids solu- 
tions. The present authors did not find data on scientific literature in order to compare the obtained results for polyamide 6 dyed fabric presented in Figure 2.

\subsection{Considerations about Environmental Impacts}

Both acetic and citric acid are biodegradable. However citric acid (COD $=0.75 \mathrm{~g}$ $\mathrm{O}_{2} / \mathrm{g}$ ) demands approximately $70 \%$ of oxygen required for biodegradation of the organic matter when compared to acetic acid $\left(\mathrm{COD}=1.07 \mathrm{~g} \mathrm{O}_{2} / \mathrm{g}\right)$. Chemical oxygen demand (COD) is defined as the amount of dissolved oxygen to oxidize and stabilize a sample when organic or inorganic matter of sample solution is responsive by a strong chemical oxidant. The COD value indicates the mass of oxygen consumed per liter of solution and expressed in milligrams per liter $(\mathrm{mg} / \mathrm{L})$. The higher the chemical oxygen demand, the higher the amount of pollution in the water sample. However, COD is considered one of the important quality control parameter of an effluent in wastewater treatment facility [26].

In adsorption experiments, the affinity of citric acid to soil adsorption sites was greater than acetic acid and this is relevant to the biodegradation of organic pollutants [27]. Furthermore, present acetic acid in textile wastewater has a significant influence on pollutant decomposition during the Fenton process. It significantly deteriorates the conditions of wastewater treatment which affects the process efficiency. Despite of results of the treatment depend on the concentration acetic acid and on the initial composition of the wastewater, acetic acid can also present a negative effect on the decomposition of pollutants, hampering their mineralization [28].

\subsection{Considerations about Occupational Health Impacts}

The textile industry consists of several processes including dyeing in which due to the nature of the work and its exposures, workers may frequently complain about respiratory symptoms. Studies indicated that system respiratory of textile-dyeing workers presented acute and chronic respiratory symptoms more prevalent [29]. The utilization of less harmful products can contribute to improving the working environment. The main toxic acids employed in synthetic textile mills are acetic, formic, oxalic and sulfuric acid [30].

Diluted acetic acid, such as in the same degree of vinegar (near 5\%), is not harmful. However, the acetic acid for textile industry is marketed, stocked and handled before and during dilution in glacial form $(<99.5 \%)$, which is harmful (by inhalation, skin contact or ingestion), corrosive and inflammable. The exposure and handling of glacial acetic acid without appropriate Personal Protective Equipment (PPE) can cause injuries and other damages to worker health. On other hand, citric acid stocking and handling is safe and does not need PPE [31] [32].

The Brazilian Labor Legislation Standard, known as Brazilian Regulatory Rule Number 15 (NR-15) [33], regulates and provides guidance on mandatory procedures related to occupational safety and health and rules about exposition le- 
vels and it was based on American Conference of Governmental Industrial Hygienists of United States (ACIGH-USA) [34]. According Brazilian NR-15, Annex $\mathrm{XI}$ [35], the limits of absorption tolerance through the respiratory tract are 8 ppm or $20 \mathrm{mg}$ per cubic meter of air for acetic acid and $4 \mathrm{ppm}$ or $7 \mathrm{mg}$ per cubic meter of air for formic acid. For both the associate insalubrity is considered medium degree. Besides, acetic and formic acid present unpleasant odor and are irritating to the respiratory tract. Otherwise, Brazilian NR-15, Annex XI [35] does not establish limits concerning citric acid.

In addition, according to the Brazilian Law 10357/2001 [36] and Brazilian Edict 1274/03 [37] [38], acquisition and commercial use of acetic acid are controlled. On other hand, citric acid can be acquired without control in form of powder which facilitates its handling and application.

In this way, it is evidenced that the alternative employment of citric acid in textile industry could reduce the toxicity and insalubrity associated to the exposure and handling of other toxic and harmful chemicals.

\subsection{Considerations about the Commercial Viability of Citric Acid Use}

Textile industry employs generally commercial grade reagents. In this way, respect the comparison of commercial grade citric and acetic acid prices, citric acid is from one-third to one-half more expensive [39] [40].

At the same time, probably much more significant than the cost difference, there are other resistance aspects related to the plain conventionality (without considering the possible options) of the employment of acetic acid solution in textile processes and, in the case of alternative employment of citric acid, the necessity of previous dissolution of this acid from the solid state to a liquid solution by agitation. However, it should be pointed that, despite of easier dissolution, acetic acid need be also diluted before its employment in these processes. On the other hand, notwithstanding additional cost and the need of previous dissolution by stirring, citric acid could be advantageous for some formulations. Furthermore, doubtless citric acid is safer regarding work occupational health and environmental aspects.

However, it is noteworthy that, despite of these preliminary considerations, only the analysis of real and representative industrial scale results could validate the cost and other possible advantages provided by the use of citric acid.

\section{Conclusion}

The results of present study showed that citric acid could be a promising alternative to chemical textiles, mainly, for acetic acid replacement in dyeing process. Both ones, acetic and citric acid, can be utilized in adjustment of $\mathrm{pH}$ in dye bath. The dyeing experiments showed that there were no significant commercial color differences between the fabrics of polyester and polyamide 6 dyed employing acetic or citric acid. There was no statistically significant difference among po- 
lyester dyeing processes. Otherwise, the differences observed for polyamide 6 dyeing processes could be related to the efficiency of citric acid as a sequestering agent, meanwhile, the insurance on the accuracy and repeatability of the data about complex ion formation, disperse dye levelling and sequestering action should be confirmed in future studies mainly taking in account industrial scale up. Citric acid is a product of easy commercial acquisition. However, citric acid employment in textile processes is economically more expensive than acetic acid. On the other hand, notwithstanding additional cost and the need of previous dissolution by stirring, citric acid could be advantageous for some formulations.

\section{References}

[1] Zhan, B.J. and Poon, C.S. (2015) Study on feasibility of Reutilizing Textile Effluent Sludge for Producing Concrete Blocks. Journal of Cleaner Production, 101, 174-179. https://doi.org/10.1016/j.jclepro.2015.03.083

[2] Abidi, N., Errais, E., Duplay, J., Berez, A., Jrad, A., Schafer, G., Ghazi, M., Semhi, K. and Trabelsi-Ayadi, M. (2015) Treatment of Dye-Containing Effluent by Natural Clay. Journal of Cleaner Production, 86, 432-440. https://doi.org/10.1016/j.jclepro.2014.08.043

[3] Rosa, J.M., Fileti, A.M.F., Tambourgi, E.B. and Santana, J.C.C. (2015) Dyeing of Cotton with Reactive Dyestuffs: The Continuous Reuse of Textile Wastewater Effluent Treated by Ultraviolet/Hydrogen Peroxide Homogeneous Photocatalysis. Journal of Cleaner Production, 90, 60-65. https://doi.org/10.1016/j.jclepro.2014.11.043

[4] Ujhelyiova, A., Bolhova, E., Oravkinova, J., Tino, R. and Marcincin, A. (2007) Kinetics of Dyeing Process of Blend Polypropylene/Polyester Fibers with Disperse Dye. Dyes and Pigments, 72, 212-216. https://doi.org/10.1016/j.dyepig.2005.08.026

[5] Guaratini, C.C. and Zanoni, M.V.B. (2000) Corantes Texteis (“Textile Dyes"). Quimica Nova, 23, 71-78. https://doi.org/10.1590/S0100-40422000000100013

[6] Carneiro, P.A., Umbuzeiro, G.A., Oliveira, D.P. and Zanoni, V.B. (2010) Assessment of Water Contamination Caused by a Mutagenic Textile Effluent/Dyehouse Effluent Bearing Disperse Dyes. Journal of Hazardous Material, 174, 694-699. https://doi.org/10.1016/j.jhazmat.2009.09.106

[7] Pasquet, V., Perwuelz, A., Behary, N. and Isaad J. (2013) Vanillin, a Potential Carrier for Low Temperature Dyeing of Polyester Fabrics. Journal of Cleaner Production, 43, 20-26. https://doi.org/10.1016/j.jclepro.2012.12.032

[8] Lade, H., Kadam, A., Paul, D. and Govindwar, S. (2015) Biodegradation and Detoxification of Textile Azo Dyes by Bacterial Consortium under Sequential Microaerophilic/Aerobic Processes. EXCLI Journal, 14, 158-174.

[9] Khandare, R.V. and Govindwar, S.P. (2015) Phytoremediation of Textile Dyes and Effluents: Current Scenario and Future Prospects. Biotechnology Advances, 33, 1697-1714. https://doi.org/10.1016/j.biotechadv.2015.09.003

[10] Da Motta, M., Pereira, R., Alves, M.M. and Pereira, L. (2014) UV/TiO 2 Photocatalytic Reactor for Real Textile Wastewaters Treatment. Water Science and Technology, 70, 1670-1676. https://doi.org/10.2166/wst.2014.428

[11] Alkaya, E. and Demirer, G.N. (2014) Sustainable Textile Production: A Case Study from a Woven Fabric Manufacturing Mill in Turkey. Journal of Cleaner Production, 65, 595-603. 
[12] Islam, M.M., Mahmud, K., Faruk, O. and Billah, M.S. (2011) Textile Dyeing Industries in Bangladesh for Sustainable Development. International Journal of Environmental Science and Development, 2, 428-436.

http://ijesd.org/papers/164-D580.pdf https://doi.org/10.7763/IJESD.2011.V2.164

[13] Bischof Vukusic, S., Flincec Grgac, S., Budimir, A. and Kalenic, S. (2011) Cotton Textiles Modified with Citric Acid as Efficient Antibacterial Agent for Prevention of Nosocomial Infections. Croatian Medical Journal, 52, 68-75.

https://doi.org/10.3325/cmj.2011.52.68

[14] Jaeger, T., Rothmaier, M., Zander, H., Ring, J., Gutermuth, J. and Anliker, M.D. (2015) Acid-Coated Textiles (pH 5.5-6.5) - A New Therapeutic Strategy for Atopic Eczema? Acta Dermato- Venereologica, 95, 659-663. https://doi.org/10.2340/00015555-1916

[15] Islam, S., Shahid, M. and Mohammed, F. (2013) Perspectives for Natural Products Based Agents Derived from Industrial Plants in Textile Applications-A Review. Journal of Cleaner Production, 57, 2-18.

[16] Al-Mousawi, S.M., El-Apasery, M.A. and Elnagdi, M.H. (2013) Microwave Assisted Dyeing of Polyester Fabrics with Disperse Dyes. Molecules, 18, 11033-11043. https://doi.org/10.3390/molecules180911033

[17] Miljkovic, M.N., Djordjevic, D.M., Miljkovic, V.M., Stamenkovic, M. and Stepanovic, J. (2014) The Influence of $\mathrm{pH}$ Adjusted with Different Acids on the Dyeability of Polyester Fabric. Polish Journal of Chemical Technology, 16, 1-5. https://doi.org/10.2478/pjct-2014-0061

[18] Soccol, C.R., Vandenberghe, L.P.S., Rodrigues, C. and Pandey, A. (2006) New Perspectives for Citric Acid Production and Applications. Food Technology and Biotechnology, 44, 141-149.

http://www.ftb.com.hr/images/pdfarticles/2006/April-June/44-141.pdf

[19] Adeoye, A.O., Lateef, A. and Gueguim-Kana, E.B. (2015) Optimization of Citric Acid Production using a Mutant Strain of Aspergillus niger on Cassava Peel Substrate. Biocatalysis and Agricultural Biotechnology, 4, 568-574.

[20] Angumeenal, A.R. and Venkappayya, D. (2013) An Overview of Citric Acid Production. Food Science and Technology, 50, 367-370.

[21] Richter, F.H., Winkler, E.W. and Baur, R.H. (1989) The Calcium Binding Capacity of Polycarboxylates. Journal of the American Oil Chemists Society, 66, 1666-1672. https://doi.org/10.1007/BF02636199

[22] SABESP Company for Basic Sanitation of Sao Paulo State (2016) Quality of Water Supplied for Metropolitan Region of Sao Paulo. http://site.sabesp.com.br/site/interna/Default.aspx?secaoId $=40$

[23] Clark, M. (2011) Handbook of Textile and Industrial Dyeing: Principles, Processes and Types of Dyes. Elsevier Woodhead Publishing, Cambridge.

[24] Konica Minolta Sensing (2003) Precise Color Communication. https://issuu.com/konicaminoltabeu/docs/pcc_english_13? $=5765487 / 3543419$ \#sear $\underline{\mathrm{ch}}$

[25] ABNT NBR ISO 105-E01:2014 (2014) Textiles Tests for Color Fastness Part E01: Color Fastness to Water. Brazilian Association of Technical Standards (ABNT) and International Organization for Standardization (ISO), Sao Paulo (BR).

[26] Alam, T. (2015) Estimation of Chemical Oxygen Demand in Waste Water using UV-VIS Spectroscopy. Master Thesis, Simon Fraser University, Surrey (CA). http://summit.sfu.ca/system/files/iritems1/15487/etd9013_TAlam.pdf 
[27] Andrade, F.V., Mendonca, E.D.S. and Silva, I.R.D. (2013) Organic Acid Adsorption and Mineralization in Oxisols with Different Textures. Revista Brasileira de Ciencia do Solo, 37, 976-985. https://doi.org/10.1590/S0100-06832013000400015

[28] Kos, L., Michalska, K., Zylla, R. and Perkowski, J. (2012) Effect of Acetic Acid on Pollutant Decomposition in Textile Wastewater Treated by the Fenton Method. Environment Protection Engineering, 38, 29-39.

[29] Nodoushan, M.S., Mehrparvar, A.H., Loukzadeh, Z., Rahimian, M., Nodoushan, M.A.G. and Nodoushan, R.J. (2014) Evaluation of Respiratory System in Textile-Dyeing Workers. Medical Journal of the Islamic Republic of Iran, 28, 1-8. http://mjiri.iums.ac.ir/article-1-2416-en.pdf

[30] Kant, R. (2012) Textile Dyeing Industry an Environmental Hazard. Natural Science, 4, 22-26. https://doi.org/10.4236/ns.2012.41004

[31] PubChem (2017) Acetic Acid Laboratory Chemical Safety Summary for CID 176. https://pubchem.ncbi.nlm.nih.gov/compound/176\#datasheet=lcss\&section=Top

[32] PubChem (2017) Citric Acid Laboratory Chemical Safety Summary for CID 311. https://pubchem.ncbi.nlm.nih.gov/compound/citric_acid\#datasheet=lcss\&section= Top

[33] Brazilian Regulatory Rule Number 15 (NR-15) from Brazilian Ordinance 3214/78 Main Text (1978).

http://www.guiatrabalhista.com.br/legislacao/nr/nr15.htm

[34] CDC-Center of Disease Control and Prevention (USA) and the National Institute for Occupational Safety and Health (NIOSH) (2017) International Chemical Safety Cards (ICSC) Acetic Acid. http://www.cdc.gov/niosh/ipcsneng/neng0363.html

[35] Brazilian Regulatory Rule Number 15 (NR-15) from Brazilian Ordinance 3214/78 Annex XI (1978).

http://www.guiatrabalhista.com.br/legislacao/nr/nr15_anexoXI.htm

[36] Brazilian Law 10357/2001 (2001). http://www.planalto.gov.br/ccivil_03/leis/LEIS_2001/L10357.htm

[37] Brazilian Edict 1274/03 Main text (2003). http://www.pf.gov.br/servicos-pf/produtos-quimicos/legislacao/PORTARIA1274.pd $\mathrm{f}$

[38] Brazilian Edict 1274/03 Annexes (2003). http://www.pf.gov.br/servicos-pf/produtos-quimicos/legislacao/anexos-da-portaria1274-03

[39] Alibaba (2017) Glacial Acetic Acid (Industrial Grade). http://portuguese.alibaba.com/trade/search?SearchText=industrial\%2bgrade $\% 2$ bgla cial\%2bacetic\%2bacid\&selectedTab=product

[40] Alibaba (2017) Citric Acid (Industrial Grade). http://portuguese.alibaba.com/trade/search?SearchText=industrial+grade+citric $+a c$ id\&selectedTab $=$ products\&viewType $=$ GALLERY 